\title{
Siblings of 21-Hydroxylase Deficiency (Non-Salt-Losing) with Aldosterone Hypersecretion
}

\author{
Isao Morimoto, Shigeki Yamamoto, Hajime Tateishi, Singi Ueda, Youko Toda, Kazuya Zeki, \\ Kenichi Watanabe, Yoichiro Nakano, Masamichi Kashimura* and Sumiya Eto
}

\begin{abstract}
We describe siblings with the non-salt-losing form of 21-hydroxylase deficiency who had hypersecretion of aldosterone and plasma renin activity (PRA). Blood pressure and serum electrolytes in both cases were normal despite the aldosterone hypersecretion. Aldosterone secretion was elevated markedly with ACTH administration and with sodium deprivation and/or volume depletion during ACTH suppression by dexamethasone. With suppression by dexamethasone, aldosterone hypersecretion was decreased with lowering of the steroids proximal to the block in the biosynthetic pathway. However, urinary sodium excretion was decreased. These results suggest that the biosynthetic pathway for aldosterone production was preserved. Furthermore, aldosterone hypersecretion and high PRA may serve to compensate for the sodium loss which results in turn from the overproduction of the sodium-losing steroids, such as progesterone and $17 \alpha$-hydroxyprogesterone which are aldosterone antagonists.

(Internal Medicine 31: 690-694, 1992)
\end{abstract}

Key words: congenital adrenal hyperplasia

\section{Introduction}

Congenital adrenal hyperplasia due to 21-hydroxylase deficiency results in a decreased synthesis of cortisol with a consequent increase in ACTH secretion. An increased ACTH secretion leads to an overproduction of steroids proximal to the site of the block in the biosynthetic pathway, and these precursor steroids are shunted into androgen synthesis that induces virilization in females (1-3). 21-hydroxylase deficiency can be classified in the salt-losing-form characterized by mineralocorticoid and glucocorticoid deficiencies, and the non-salt-losing form (simple form) is preserved in aldosterone synthesis and has usually normal secretion or hypersecretion of aldosterone $(1,4-7)$. In this paper, we describe two siblings with the non-salt-losing form of 21-hydroxylase deficiency whose blood pressure and serum electrolytes were normal, despite hypersecretion of aldosterone.

\section{Methods}

Plasma progesterone (8), aldosterone (9) and plasma renin activity (PRA) (10) were measured by RIA in our hospital. Progesterone RIA kit was obtained from Daiichi Radioisotope Ltd, Tokyo, Japan, and aldosterone and PRA kit were from Dainabot Ltd, Tokyo, Japan. Plasma cortisol, testosterone and $\mathrm{ACTH}$, and urinary free cortisol and aldosterone were measured by RIA at Otsuka Assay Laboratories (Tokushima, Japan). Plasma 17-hydroxyprogesterone and deoxycorticosterone, and urinary pregnanediol and pregnanetriol were measured at Kitazato Biochemical Laboratories (Kanagawa, Japan).

A dexamethasone suppression test was carried out with consecutive 4-day dexamethasone $(2,2,8,8 \mathrm{mg})$ administration on $10 \mathrm{~g}$ sodium diets. Blood samples for the measurement of hormones and electrolytes were obtained at 8 a.m. on day 1 and on day 5 , and urine samples were obtained on the preceding day (day -1) and on day 4. An ACTH stimulation test was accomplished by intramuscular administration of ACTH-Z (Cortrosyn-Z, Organon, Tokyo) in dose of $0.5 \mathrm{mg} /$ day for 3 consecutive days. Blood samples were obtained at $8 \mathrm{a} . \mathrm{m}$. before the first injection and 24 hours after the third injection, and urine samples were obtained on day -1 and day 3 .

The effect of sodium deprivation on hormone secretion was examined while receiving $10 \mathrm{~g}$ of salt for at least

From the First Department of Internal Medicine and * Gynecology, School of Medicine, University of Occupational and Environmental Health, Kitakyushu

Received for publication July 22, 1991; Accepted for publication January 14, 1992

Reprint requests should be addressed to Dr. Isao Morimoto, the First Department of Internal Medicine, School of Medicine, University of Occupational and Environmental Health, 1-1, Iscigaoka, Yahatanishi-ku, Kitakyushu 807, Japan 
7 days, followed by $3 \mathrm{~g}$ of salt for 3 days. Urine samples were obtained final days of the $10 \mathrm{~g}$ and $3 \mathrm{~g}$ salt diets. PRA and aldosterone responses after 2 hours of upright (Case 1) and 2 hours of upright plus $20 \mathrm{mg}$ of furosemide intracutaneous administration (Case 2) were examined during $10 \mathrm{~g}$ and $3 \mathrm{~g}$ salt diets.

\section{Case Report}

\section{Case 1}

A 16-year-old elder sister was referred to our clinic because of amenorrhea and virilization. The clitoral enlargement was pointed out in early infancy. At the age of 10, heterosexual precocity was observed. In July 1990, she consulted a gynecologist in our hospital and was found to have abnormalities of external genitalia.

Physical examination showed as follows: height $151 \mathrm{~cm}$, weight $50 \mathrm{~kg}$, blood pressure $100 / 50 \mathrm{mmHg}$. Her habitus was demonstrated to be apparently masculinization. Virilization consisted of hypertrichosis, acnes and low voice. Ambiguity of the external genitalia was revealed, such as enlargement of the clitoris, small outlet of the vagina, and urethral orifice located into the vagina. Serum electrolytes were determined on several occasions on regular diets $(10 \mathrm{~g} \mathrm{NaCl})$ : serum sodium $136-140 \mathrm{mEq} / \mathrm{l}$, potassium $3.6-4.5 \mathrm{mEq} / 1$ and chloride $98-100 \mathrm{mEq} / \mathrm{l}$.

Case 2

A 12-year-old younger sister was admitted together with Case 1 because of amenorrhea and virilization. Her clinical course and physical findings were similar to those of her elder sister. Serum sodium was $138-141 \mathrm{mEq} / \mathrm{l}$, potassium was $3.8-4.1 \mathrm{mEq} / \mathrm{l}$, and chloride was $100-102 \mathrm{mEq} / 1$ on a regular diet.

\section{Hormone studies}

Urinary and plasma hormone levels are shown in Table 1. In both cases, hormonal and electrolyte levels in serum and urine were similar before and after various procedures. Plasma and urinary steroids proximal to the site of the block by 21-hydroxylase in the biosynthetic pathway and C19 steroids were elevated, and the precursor steroids were decreased to normal by 4-day of dexamethasone administration (Table 1). On the other hand, they had normal cortisol and increased aldosterone levels in plasma and urine, which were decreased by dexamethasone. However, the aldosterone levels were not completely suppressed. PRA was elevated despite aldosterone oversecretion before and during $\mathrm{ACTH}$ suppression. Urinary excretion of sodium was decreased with the dexamethasone administration in both cases.

After consecutive 3-day ACTH-Z administration $(0.5 \mathrm{mg} / \mathrm{day})$, all urinary and plasma steroids including cortisol and aldosterone were elevated and urinary sodium excretion was decreased in both cases (Table 2). Blood pressure and serum electrolytes were normal among these procedures.

In Case 1, the effect of sodium deprivation on aldosterone secretion and PRA was examined during a maintenance therapy of $0.75 \mathrm{mg}$ dexamethasone (Table 3 ). Plasma and urinary aldosterone levels were elevated after sodium deprivation, and urinary sodium excretion decreased. PRA did not change. Furthermore, PRA and plasma aldosterone levels increased with 2 hour

Table 1. Urinary and Plasma Hormone Levels after 4 Days of Dexamethasone $(2,2,8,8 \mathrm{mg})$; Suppression Test on $10 \mathrm{~g}$ Salt Diet

\begin{tabular}{|c|c|c|c|c|c|}
\hline & \multirow[t]{2}{*}{ Normal range } & \multicolumn{2}{|c|}{ Case 1} & \multicolumn{2}{|c|}{ Case 2} \\
\hline & & before & after & before & after \\
\hline \multicolumn{6}{|l|}{ Serum } \\
\hline Progesterone & $(0.67>\mathrm{ng} / \mathrm{ml})^{*}$ & 0.71 & 0.63 & 2.6 & 0.73 \\
\hline $17 \mathrm{OH}$-progesterone & $(0.3-0.85 \mathrm{ng} / \mathrm{ml})^{*}$ & 95.6 & 1.40 & 163.0 & 1.71 \\
\hline Testosterone & $(10-60 n g / d)$ & 190.0 & 24.7 & 210.0 & 16.0 \\
\hline Cortisol & $(2.7-15.5 \mu \mathrm{g} / \mathrm{dl})$ & 6.20 & $1.00>$ & 8.8 & $1.00>$ \\
\hline DOC & $(0.03-0.33 \mathrm{ng} / \mathrm{ml})$ & 2.04 & 0.09 & 2.60 & 0.10 \\
\hline Aldosterone & $(52-175 \mathrm{pg} / \mathrm{ml})$ & 324.9 & 189.40 & 331.0 & 156.6 \\
\hline PRA & $(0.5-2.0 \mathrm{ng} / \mathrm{ml} / \mathrm{h})$ & 9.20 & 12.40 & 4.90 & 12.40 \\
\hline ACTH & $(4.4-48.0 \mathrm{pg} / \mathrm{ml})$ & 79.80 & $4.00>$ & 52.10 & $4.00>$ \\
\hline \multicolumn{6}{|l|}{ Urine } \\
\hline $17 \mathrm{OHCS}$ & $(1.9-6.1 \mathrm{mg} / \mathrm{day})$ & 2.5 & 1.3 & 2.0 & 0.5 \\
\hline Pregnanediol & $(0.03-0.16 \mathrm{mg} / \mathrm{day})^{*}$ & 1.47 & 0.25 & 1.64 & 0.17 \\
\hline Pregnanetriol & $(1.5>\mathrm{mg} / \mathrm{day})$ & 3.29 & 0.28 & 9.68 & 0.21 \\
\hline Free cortisol & $(35-150 \mu \mathrm{g} /$ day $)$ & 61 & 15 & 46 & $10>$ \\
\hline Aldosterone & $(10>\mu \mathrm{g} /$ day $)$ & 29.9 & 19.0 & 20.0 & 12.0 \\
\hline $\mathrm{Na}$ & (mEq/day) & 161 & 133 & 180 & 128 \\
\hline K & (mEq/day) & 63 & 53 & 63 & 49 \\
\hline $\mathrm{Cl}$ & (mEq/day) & 157 & 115 & 119 & 129 \\
\hline
\end{tabular}

17OH progesterone: $17 \alpha$-hydroxyprogesterone, DOC: 11 -deoxycorticosterone

* Normal range of follicular phase 


\section{Morimoto et al}

Table 2. Urinary and Plasma Hormonal Levels before and after 3-Day ACTH-Z (0.5 mg) Administration on $10 \mathrm{~g}$ Salt Diets

\begin{tabular}{|c|c|c|c|c|c|}
\hline & \multirow[t]{2}{*}{ Normal range } & \multicolumn{2}{|c|}{ Case 1} & \multicolumn{2}{|c|}{ Case 2} \\
\hline & & before & after & before & after \\
\hline \multicolumn{6}{|l|}{ Plasma } \\
\hline Progesterone & $(0.67>\mathrm{ng} / \mathrm{ml})^{*}$ & 2.90 & 8.10 & 6.10 & 12.10 \\
\hline $17 \mathrm{OH}$ progesterone & $(0.3-0.85 \mathrm{ng} / \mathrm{ml})^{*}$ & 91 & 348 & 131 & 522 \\
\hline Testosterone & $(10-60 \mathrm{ng} / \mathrm{dl})$ & 360 & 470 & 324 & 487 \\
\hline DOC & $(0.03-0.33 \mathrm{ng} / \mathrm{ml})$ & 1.74 & 3.84 & 3.42 & 6.61 \\
\hline Cortisol & $(2.7-15.5 \mu \mathrm{g} / \mathrm{dl})$ & 11.5 & 45.0 & 13.3 & 38.7 \\
\hline \multicolumn{6}{|l|}{ Urine } \\
\hline 17-OHCS & $(1.9-6.1 \mathrm{mg} /$ day $)$ & 4.5 & 20.6 & 2.6 & 18.1 \\
\hline Pregnanediol & $(0.03-0.16 \mathrm{mg} /$ day $)$ & 2.86 & 8.51 & 2.15 & 4.79 \\
\hline Pregnanetriol & $(1.5>\mathrm{mg} /$ day $)$ & 17.0 & 116.0 & 19.5 & 92.1 \\
\hline Free cortisol & $(35-160 \mu \mathrm{g} / \mathrm{day})$ & 83 & 1,940 & 39 & 1,520 \\
\hline Aldosterone & (10> $\mu \mathrm{g} /$ day $)$ & 32.0 & 96.0 & 20.0 & 77.0 \\
\hline $\mathrm{Na}$ & (mEq/day) & 129 & 59 & 150 & 109 \\
\hline K & (mEq/day) & 58 & 49 & 46 & 44 \\
\hline $\mathrm{Cl}$ & (mEq/day) & 125 & 88 & 119 & 122 \\
\hline
\end{tabular}

17OH-progesteronc: $17 \alpha$-hydroxyprogesterone, DOC: 11 -deoxycorticosterone

* Normal range of follicular phase

Table 3. Effect of Sodium Deprivation on Plasma and Urinary Hormone Levels and Urinary Electrolytes during $0.75 \mathrm{mg}$ of Dexamethasone for Maintenance Therapy in Case 1

\begin{tabular}{lrrr}
\hline & & $10 \mathrm{~g}$ Salt & $3 \mathrm{~g} \mathrm{Salt*}$ \\
\hline Plasma & & & \\
$\quad$ Progesterone & $(\mathrm{ng} / \mathrm{ml})$ & 7.6 & 2.1 \\
17OH-progesterone & $(\mathrm{ng} / \mathrm{ml})$ & 118.0 & 60.4 \\
PRA & $(\mathrm{ng} / \mathrm{ml} / \mathrm{h})$ & 5.3 & 5.4 \\
ACTH & $(\mathrm{pg} / \mathrm{ml})$ & 93.6 & 32.4 \\
Urine & $(\mu \mathrm{g} / \mathrm{dl})$ & 11.0 & 23.0 \\
Aldosterone & $(\mathrm{mEq} / \mathrm{day})$ & 121 & 69 \\
$\mathrm{Na}$ & $(\mathrm{mEq} / \mathrm{day})$ & 31 & 32 \\
$\mathrm{~K}$ & $(\mathrm{mEq} / \mathrm{day})$ & 136 & 62 \\
$\mathrm{Cl}$ & & & \\
\hline
\end{tabular}

PRA: plasma renin activity, 170H-progesterone: 17-hydroxyprogesterone

* $3 \mathrm{~g}$ salt diet for 3 days upright posture on both regular and low sodium diets (Table 4). However, those responses were significantly greater with sodium deprivation than those with $10 \mathrm{~g}$ sodium diet. The effect of upright posture plus $20 \mathrm{mg}$ of furosemide administration on low sodium diet without suppression with dexamethasone was examined in Case 2. PRA increased 8.7 to more than $22 \mathrm{ng} / \mathrm{ml} / \mathrm{h}$ and plasma aldosterone level was from 624 to $1,491 \mathrm{pg} / \mathrm{ml}$.

\section{Gene analysis of the family}

In 21-hydroxylase B gene of both siblings and parents neither deletion nor gene conversion was revealed by PCR analysis which was previously described by Kinoshita et al (11).

\section{Clinical course after treatment of dexamethasone \\ Both patients were treated with $1 \mathrm{mg}$ of dexame- thasone, followed by $0.75 \mathrm{mg}$ as a maintenance dose.}

Table 4. Effect of 2 Hour Upright Posture and 2 Hour Upright Posture Plus $20 \mathrm{mg}$ of Furosemide Administration during a $10 \mathrm{~g}$ and a $3 \mathrm{~g}$ Salt Diets

\begin{tabular}{|c|c|c|c|c|c|}
\hline & & \multicolumn{2}{|c|}{$10 \mathrm{~g}$ Salt } & \multicolumn{2}{|c|}{$3 \mathrm{~g} \mathrm{Salt*}$} \\
\hline & & beforc & after** & before & after*** \\
\hline \multicolumn{6}{|l|}{ Case 1} \\
\hline PRA & $(\mathrm{ng} / \mathrm{ml} / \mathrm{h})$ & 6.0 & 11.7 & 5.9 & 23.6 \\
\hline Aldosterone & $(\mathrm{pg} / \mathrm{ml})$ & 111 & 473 & 176 & 702 \\
\hline \multicolumn{6}{|l|}{ Case 2} \\
\hline PRA & $(\mathrm{ng} / \mathrm{ml} / \mathrm{h})$ & & & 8.7 & $22<$ \\
\hline Aldosterone & $(\mathrm{pg} / \mathrm{ml})$ & & & 624 & 1,491 \\
\hline
\end{tabular}

PRA: plasma renin activity, $* 3 \mathrm{~g}$ salt diet for 3 days, ${ }^{* *}$ values after upright posture or upright plus furosemide administration 
Plasma ACTH levels were suppressed, and plasma levels of precursor steroids blocked by 21-hydroxylation became normal and levels of aldosterone decreased to reach the upper normal level in both cases. Blood pressure and serum electrolytes remained normal level on regular diets in both cases. In both cases virilization was improved along with the lowering of plasma testosterone levels in both cases.

\section{Discussion}

Adrenal 21-hydroxylase acts on the conversions of progesterone to deoxycorticosterone and $17 \alpha$-hydroxyprogesterone to cortisol. In patients with the non-saltlosing form of 21-hydroxylase deficiency, defective C21-hydroxylation results in a block in the conversion of $17 \alpha$-hydroxyprogesterone to 11-deoxycortisol and cortisol, and resultant increased ACTH secretion (1-3). Despite blockade in the pathway of glucocorticoid, plasma and urinary cortisol levels in the present cases were preserved to normal levels by the excess ACTH secretion because 21-hydroxylation was not completely blocked. It was also suggested by the further secretion of cortisol with the administration of $\mathrm{ACTH}-\mathrm{Z}$ administration.

On the other hand, 21-hydroxylation in the mineralocorticoid biosynthesis in the adrenal gland is preserved in patients with the non-salt-losing form (5-7). Previous studies $(5-7)$ demonstrate that untreated patients with 21-hydroxylase deficiency usually have normal secretion or hypersecretion of aldosterone. Pardini et al (12) and Fiet et al (13) observed impaired mineralocorticoid hormone responses to $\mathrm{ACTH}$ stimulation in subjects with the non-salt-losing form of 21-hydroxylase deficiency, and suggested the presence of a mild defect of the mineralocorticoid biosynthetic pathway in that form. The present cases had higher levels of aldosterone in urine and blood. Aldosterone and deoxycorticosterone secretions were elevated along with the steroids proximal to the block in the mineralocorticoid pathway by ACTH administration. Furthermore, aldosterone secretion was elevated markedly with the stimulus of sodium deprivation and volume depletion during ACTH suppression by dexamethasone. These results suggest that the biosynthetic pathway for aldosterone production is preserved in the present patients.

Despite the increases of plasma and urinary aldosterone and PRA, blood pressure and serum electrolytes were normal in the present cases. It seems that the overproduction of aldosterone is secondary to a relative sodium depletion. Excess ACTH secretion leads to the overproduction of progesterone and 17 $\alpha$-hydroxyprogesterone which might cause a loss of sodium by antagonizing the effect of aldosterone (14-19). Kowarski et al (6) and Bartter et al (7) have reported cases of the non-saltlosing form of 21-hydroxylase deficiency who did not have hypertension or hypokalemia despite aldosterone hypersecretion, and suggest that the overproduction of aldosterone represents an attempt to compensate for the sodium loss which results in turn from the overproduction of weak sodium-losing steroids such as progesterone and $17 \alpha$-hydroxyprogesterone. We do not know whether the plasma levels of progesterone and $17 \alpha$-hydroxyprogesterone observed in the present cases were high enough to lead to a loss of sodium. However, with lowering of ACTH secretion by dexamethasone, the secretion of antagonistic hormones descreased, and urinary sodium excretion decreased despite the lowering of aldosterone secretion in both cases at the same time. These results suggest that an increased production of antagonistic factors might be the primary cause for a compensatory increase in the aldosterone secretion. The renin-aldosterone system plays an important role in the aldosterone hypersecretion in the present patients. Furthermore, the aldosterone hypersecretion in these patients decreased to normal without changes of serum electrolytes or blood pressure with the long-term treatment of dexamethasone.

The abnormality of this disorder is due to an autosomal recessive gene (20). Predictions of carrier status can be made by kinship by gene analysis $(11,13,21)$. However, we could not reveal the deletion or gene conversion in the 21-hydroxylase $B$ gene in the siblings or parents. Therefore, gene abnormality in the present patients may be a point mutation in the $17 \alpha$-hydroxylase $\mathrm{B}$ gene that leads to a mild enzymatic deficiency, resulting in the non-salt-losing form.

\section{References}

1) Grumbach MM, Conte FA. Congenital adrenal hyperplasia. In: Textbook of Endocrinology, 7th edition, Wilson JD, Foster DW, Eds. W B Saunders, Philadelphia, 1985.

2) Bongiovanni AM, Eberlein WR. Defective steroidal biogenesis in congenital adrenal hyperplasia. Pediatrics 21: 661, 1958.

3) Bongiovanni AM. In vitro hydroxylation of steroids by whole adrenal homogenates of beef, normal man, and patients with the adrenogenital syndrome. J Clin Invest 37: 1342, 1958.

4) Bongiovanni AM, Eberlein WR. Defects in steroidal metabolism of subjects with adrenogenital syndrome. Metab Clin Exp 10: 917, 1961.

5) Bryan GT, Kliman T, Bartter FC. Impaired aldosterone production in salt losing congenital adrenal hyperplasia. J Clin Invest 44: 957, 1965.

6) Kowarski A, Finkelstein JW, Spaulding JS, Holman GH, Migeon GH. Aldosterone secretion rate in congenital adrenal hyperplasia. A discussion of the theories on the pathogenesis of salt-losing form of the syndrome. J Clin Invest 44: 1505, 1965.

7) Bartter FC, Henkin RI, Bryan GT. Aldosterone hypersecretion in non-salt-losing congenital adrenal hypcrplasia. J Clin Invest 47: 1742, 1968.

8) Makino T, Oka C, Hara T, et al. Estradiol and progesterone in women measured by new coated tube kit. Hormone to Rinshou 36: 975, 1988.

9) Ogihara $T$, Iinuma $K$, Nishi $K$, et al. A non-chromatographic non-extraction radioimmuno assay for serum aldosterone. J Clin Endocrinol Metab 45: 726, 1977. 


\section{Morimoto et al}

10) Iinuma $\mathrm{K}$, Ikeda $\mathbf{I}$, Takai $\mathrm{M}$, et al. A simple solid phase radioimmunoassay for plasma renin activity. Folia Endocrinol Jpn 57: 1654,1981 .

11) Kinoshita $E$, Matsumoto $T$, Kondoh $T$, Yoshimoto $M$, Niikawa $\mathrm{N}$, Tsuji $\mathrm{Y}$. Deletion pattern in 21-hydroxylase gene detected by polymerase chain reaction. Acta Paediatr Jpn 33: 1, 1991.

12) Pardini DP, Kater CE, Vieira JGH, Biglieri EG. Impaired mineralocorticoid hormone responses to adrenocorticotropin stimulation: Additional characterization of heterozygosity for the 21-hydroxylase deficiency type of congenital adrenal hyperplasia. J Clin Endocrinol Metab 57: 1061, 1983.

13) Fiet J, Gueux B, Raux-Demay MC, et al. Increased plasma 21-deoxycorticosterone (21-DB) levels in late-onset adrenal 21-hydroxylase deficiency suggest a mild defect of the mineralocorticoid pathway. J Clin Endocrinol Metab 68: 542, 1989.

14) Landau RL, Lugibihl $\mathrm{K}$. Inhibition of sodium-retaining influence of aldosterone by progesterone. J Clin Endocrinol Metab 18: 1237,1958

15) Jacobs DR, Van der Pall J, Cabrilove JL, Soffer LJ. 17-hydroxyprogesterone: A salt-losing steroid: relaxation to congenital adrenal hyperplasia. J Clin Endocrinol Metab 21: 909, 1961.
16) George JM, Saucier G, Bartter FC. Is there a potent naturally occurring sodium-losing steroid hormone. J Clin Endocrinol Metab 25: 621, 1965.

17) Landau RL, Lugibihl K. Inhibition of the sodium-retaining influence of aldosterone by progesterone. J Clin Endocrinol Metab 18: 1237, 1958.

18) Landau RL, Lugibihl K, Dimick DF. Metabolic effects in man of steroids with progestational activity. Ann NY Acad Sci 71: 588,1958

19) Kagawa CM. Blocking urinary electrolyte effect of deoxycorticosterone with progesterone in rats. Proc Soc Exp Biol Med 99: 705,1958

20) Childs B, Grumbach MM, Van Wyk JJ. Virilizing adrenal hyperplasia; a genetic and hormonal study. J Clin Invest 35: 213, 1956.

21) Dupot B, Virdis R, Lerner AJ, Nelson C, Pollack MS, New MI. Distinct HLA-B Antigen Associations for Salt-wasting and Simple Virilizing Forms of Congenital Adrenal Hyperplasia Due to 21-hydroxylase Deficiency. In: Histocompatibility Testing, Albert ED, Baur MP, Wayer WR, Eds. Spinger-Verlag, New York, 1984. 